\title{
Ethnobotanical survey of plant species utilised as spices among the indigenous people of Bayelsa State, Nigeria
}

\author{
Ihinmikaiye Samuel Olatokunbo ${ }^{1,2, *}$, Sunday Arowosegbe ${ }^{2}$, Joshua \\ Kayode $^{2}$ and Ayodele Oyedeji ${ }^{3}$
}
${ }^{1}$ Department of Biology, Federal University, Otuoke, Nigeria. *Email: Ihinmikaiye.samuel@yahoo.com.
${ }^{2}$ Department of Plant Science, Ekiti State University, Ado-Ekiti, Nigeria.
${ }^{3}$ Department of Biological Sciences, Niger Delta University, Wilberforce Island, Nigeria.

\begin{abstract}
Plant species used as spices in Bayelsa State, Nigeria, were assessed in this study. A total of twenty four spicy plants were identified. This included a fungal species and twenty three plant species. These species were of diverse life forms $(25 \%$ trees; $8 \%$ shrubs, $58 \%$ herbs and $4 \%$ grasses). The study also revealed that the spicy plants identified were heterogeneously distributed across the three senatorial zones of the State. Fruits/seeds were the most utilized parts of the indigenous spicy plants identified. $63 \%$ of the identified spicy plants were sourced from the wild and 38\% were cultivated in the State. Parts of the plants utilized for spices were fruits, seeds, leaves, shoots, bulbs, rhizomes and in some cases the entire-part. Fruits and seeds dominated the parts used (46\%), while rhizome and the entire-parts were the least utilized parts (4\%) for spices in the study area. Most of the methods employed in harvesting the spicy plants were annihilative and inhibitory. Also environmental pollution among other factors threatens the existence of the spicy plants growing in the wild in the study area. In conclusion conservational strategies that will ensure sustainable use of the identified spicy plant species were proposed.
\end{abstract}

Keywords: Spicy plants; Conservation; Bayelsa State; Indigenous people.
Received

May 1, 2018

Accepted

August 9, 2018

Released

August 31, 2018

Full Text Article

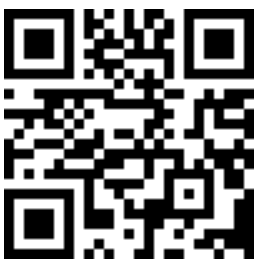

ORCID

(1) 0000-0001-9793-6224 Ihinmikaiye Samuel Olatokunbo

(1) 0000-0003-0395-3117 Sunday Arowosegbe

(1) 0000-0002-7467-5276 Joshua Kayode

(1) 0000-0003-2041-6313 Ayodele Oyedeji 


\section{Introduction}

Bayelsa (Nigeria) is a State with rich Ijaw cuisine prepared not without tangs of spicy plants which make delicacies from the region a toothsome dessert. Spices are plant materials (seeds, fruits, leaves, root buds, whole plants) traditionally use for flavouring, garnishing or improving the quality of food. They occupy pivotal role in the realm of traditional health care system as medicine and perfumes, and cosmetics for traditional rites (MacMillian, 1984; Kamala, 2008). FAO (2005) and Kayode and Ogunleye (2008) asserted that spices are the most commonly used plants in Nigeria and Africa at large, and such plants are usually aromatic and pungent by nature (Achinewu et al., 1995) due to the phytochemicals and essential oils embedded in them (MacMillian, 1984). Literally, these phytochemicals (from evolutionary view) are used to warn-off predators. Be that as it may, fundamental to ecological functions are the interaction between man and plant. Yet, spicy plants are important to the dynamism of the relationship and must be conserved because a shift in their floristic composition may affect a whole awful lot. Bayelsa State is rich in spicy plants; some are cultivated while a higher proportion grows in the wild. Spicy plants are part of the Non Timber Forest Products (NTFPs), and are easily prepared by milling, pounding, smashing and cooking otherwise simply by adding or mixing (Mathewo, 2015). Considerable knowledge of these botanicals are in the possession of indigenous women who uses spices for domestic and culinary purposes. Like every other NTFPs, spices have economic value and are potential source of employment opportunity (Soladoye and Sonibere, 2003; Olife et al., 2013).

\section{Materials and methods}

\section{The study area}

The study was conducted in Bayelsa State which is one of the six states that make up the South-South geopolitical zones of Nigeria (Figure 1). It is geographically located on Lat. $4^{\circ} 45^{\prime} \mathrm{N}$, long $6^{\circ} 05^{\prime} \mathrm{E}$ in the very heart of the Niger Delta Region of Nigeria. The state has a population figure fairly above $1,704,515$ (2006, Census) and a land mass area of about $9415.85 \mathrm{~km}^{2}$. Factually, Bayelsa State derived its name from the acronym of three Local Government Areas (LGAs): Balga, Yelga and Salga which were formally part of old Rivers State whence Bayelsa State was carved up in 1996. And the three LGAs were what constituted what is now known as the 8 LGAs (Brass, Nembe, Ogbia, Southern Ijaw, Kolokuma/ Opokuma, Ekeremor, Sagbama and Yenagoa) that make up present Bayelsa State. The state is located in the low lying deltaic plain and is criss-cross by network of Rivers Niger distributaries. The soil consist of what the geologic units refers as sedimentary alluvium and abandoned beach ridges formed in the early Holocene epoch (Akpokodje, 1989). Physiographically, a number of soil types exist in the state these include: sandy loamy, loamy sandy, silty loamy, transported sandy soil and silty-clayeymud locally known as chikoko. Vital soil nutrients and organic matter are embedded in the various soil types; they find expression in the vigorous vegetation of the State. Two distinctive types of vegetative zones exist in the State: tropical rain forest and mangrove swamp forest. The temperature ranges between $26^{\circ} \mathrm{C}$ to $31^{\circ} \mathrm{C}$, with high relative humidity depending on the season of the year. High rain fall occur between April 


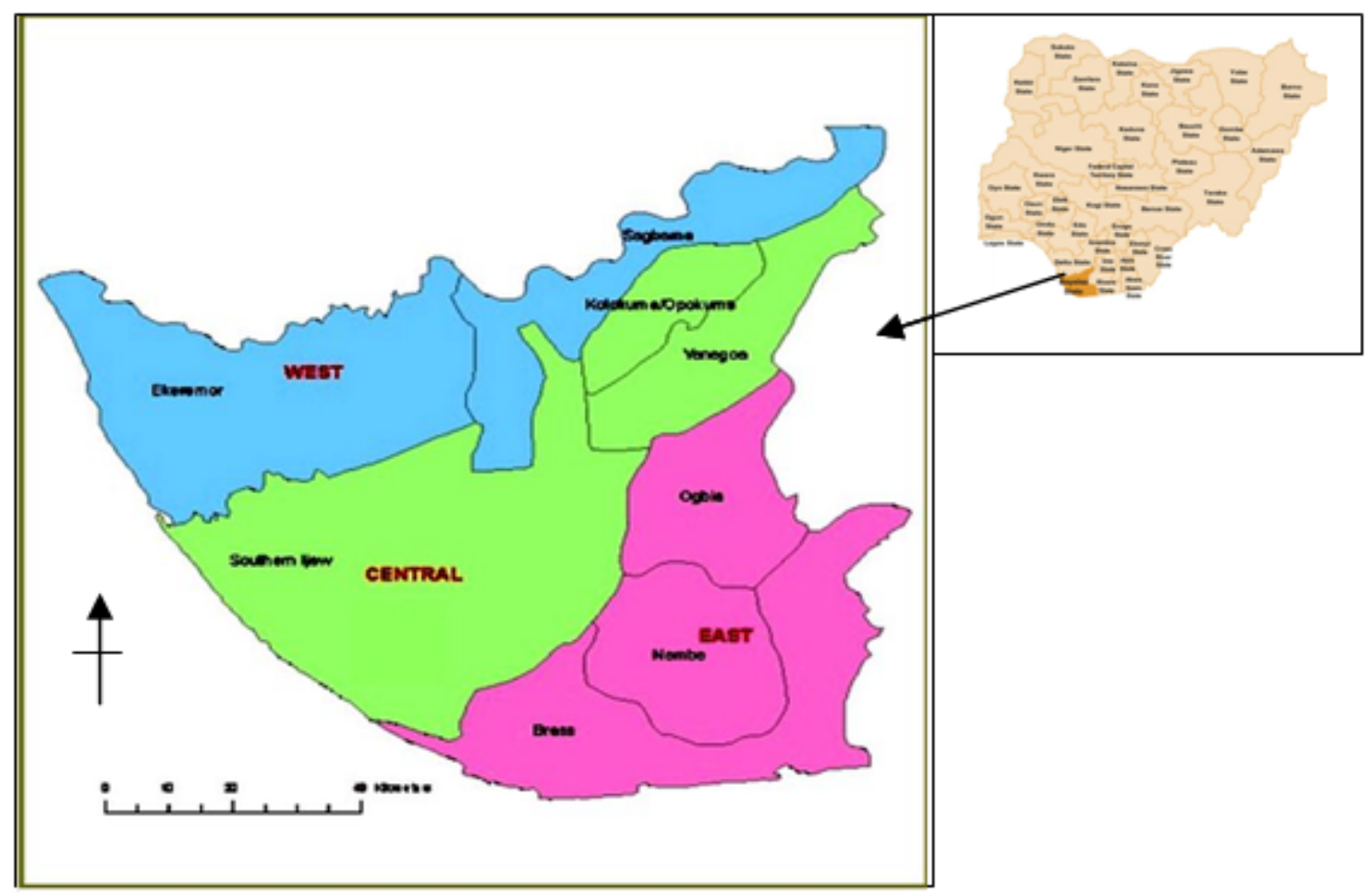

Figure 1. Map of Bayelsa State, Nigeria.

and November and dry season with sparse rainfall between December and March.

\section{Methodology}

The Approaches of Kayode (2002 and 2005) were employed for the study: these consist of a combination of social survey and direct field observation. The 8 LGAs of Bayelsa State were divided into 3 zones (Bayelsa East (BE), Bayelsa West (BW) and Bayelsa Central (BC) based on the existing geopolitical delineation. Five communities were selected from each of the LGAs. (In other words, 40 villages that were still relatively free from urban influences) were selected for the study. 10 indigenous people that have maintain a continuous domicile for a minimum period of 10 years were selected and interviewed with the aid of a semi structured questionnaire matrix.

The interviews were carried out in manner that allow for fairly open framework, focus conversational, and two way communication as suggested by Kayode and Ogunleye (2008).

Plant species whose seeds, leave, fruits, rhizomes, bulb or whole parts are used for spicy purposes by the respondents were identified and their voucher specimen was collected. The sources of such plant species, their life form, methods of harvest and utilization were also noted and documented. Secondary information was obtained from group interviews conducted with women at mills and fishing camps. Field information was confirmed and compared with floras of the region (including those of Hutchinson and Dalziel, 1954; Keay et al., 1964; Gill, 1992; Nyananyo, 2006). Relative abundant status of the identified spicy plants was determined based on the time taken to assess a sample of the species within the vegetation of the communities (after Ronger et al., 1988). Where a sample was sighted less than $1 \mathrm{~h}$, it was considered as very abundant; it was abundant when sighted $<23 \mathrm{~h}$ and it was 
considered as frequent when sighted within $24 \mathrm{~h}, 3$ days of searching. It was considered as occasional when found $>1$ week, but rare when it takes more than 1 week to assess it.

Meanwhile, level of spicy plants distribution within the 3 geopolitical zones where determined using $\mathrm{X}^{2}$ Test.

\section{Results and discussion}

A total of 24 spice plants were assessed in the study area (Table 1). One of the species assessed is the edible mushroom (Agaricus sp.). The others are of plant origin: their life forms comprise

Table1. List of spices utilized among major ethnic group in Bayelsa State of Nigeria.

\begin{tabular}{|c|c|c|c|c|c|}
\hline & Family name & Botanical names & Vernacular names & LF* $^{*}$ & Part utilize \\
\hline 1 & Zingiberaceae & Aframomum citratum & $\begin{array}{l}\text { Fisani, sani, ehie, alligator } \\
\text { pepper }\end{array}$ & $\mathrm{H}$ & Seed \\
\hline 2 & Zingiberaceae & Aframomum danielli & $\begin{array}{l}\text { Ehie, sani, Fisani, Alligator } \\
\text { pepper }\end{array}$ & $\mathrm{H}$ & “ \\
\hline 3 & Zingiberaceae & $\begin{array}{l}\text { Aframomum } \\
\text { melegueta }\end{array}$ & $\begin{array}{l}\text { Ataiko, Grains of paradise, } \\
\text { Fisani }\end{array}$ & $\mathrm{H}$ & “ \\
\hline 4 & Polyporaceae & $\begin{array}{l}\text { Agaricus sp., Lentinus } \\
\text { tuberregium }\end{array}$ & Akasi, Edible Mushroom & $\mathrm{Fb}$ & $\begin{array}{l}\text { Entire } \\
\text { section }\end{array}$ \\
\hline 5 & Euphorbiaceae & Alchornea cordifolia & Epie tin, Christmas bush & $\mathrm{S}$ & Fresh shoot \\
\hline 6 & Alliaceae & Allium сера & Onion (yabase ayou) & $\mathrm{H}$ & Bulb/leaf \\
\hline 7 & Alliaceae & Allium sativum & Garlic, gali & $\mathrm{H}$ & Bulb \\
\hline 8 & Solanaceae & Capsicum annuum & Igina, red pepper & $\mathrm{H}$ & fruit \\
\hline 9 & Asteraceae & $\begin{array}{l}\text { Chromolaena } \\
\text { odoratum }\end{array}$ & $\begin{array}{l}\text { Gbolow furutuo, siam } \\
\text { weed }\end{array}$ & $\mathrm{H}$ & Fresh shoot \\
\hline 10 & Rutaceae & Citrus sinensis & Lila ponmo, orange & $\mathrm{T}$ & Fresh shoot \\
\hline 11 & Poaceae & Cymlopogon citratus & Beke piri, lemon grass & $\mathrm{H}$ & Leaf \\
\hline 12 & Annonaceae & Dennettia tripetala & Pepper fruit (piri tin) & $\mathrm{T}$ & Fruit/Seed \\
\hline 13 & invingiaceae & Irvingia smittii & Bakalaza tin & $\mathrm{T}$ & Seed \\
\hline 14 & Annonaceae & Monodora myristica & Arigogo,Calabash nutmeg & $\mathrm{T}$ & Seed \\
\hline 15 & Rutaceae & Murraya koenigii & Curry leaf (curi) & $\mathrm{H}$ & Leaf \\
\hline 16 & Lamiaceae & Ocimum gratissimum & Furukana, scent leaf & $\mathrm{H}$ & Leaf \\
\hline 17 & Poaceae & Pennistum purpureum & Osiia usi, elephant grass & $\mathrm{G}$ & Fresh shoot \\
\hline 18 & Piperaceae & Piper guineense & Oziza, climbing pepper & $\mathrm{H}$ & Fruit \\
\hline 19 & Cucurbiataceae & Telfairia occidentalis & Ogu seed Fluted pumpkin & $\mathrm{H}$ & Seed \\
\hline 20 & Fabaceae & Tetrapleura tetraptera & $\begin{array}{l}\text { Apaupau, pakiopaki, aidan } \\
\text { tree }\end{array}$ & $\mathrm{T}$ & Seed \\
\hline 21 & Asteroceae & Vernonia amygdalina & Kiriologbo, bitter leaf & $\mathrm{S}$ & Leaf \\
\hline 22 & Araceae & Xanthosoma mafaffa & Odu, cocoyam & $\mathrm{H}$ & Leaf/Shoot \\
\hline 23 & Annonaceae & Xylopia aethiopica & Enge, Africa pepper & $\mathrm{T}$ & Fruit/Seed \\
\hline 24 & Zingiberaceae & Zingiber officinale & Ginga & $\mathrm{H}$ & Rhizome \\
\hline
\end{tabular}

*Life Form, $\mathbf{T}=$ tree, $\mathbf{H}=$ herb, $\mathbf{S}=$ shrub, $\mathbf{F b}=$ fruiting body, $\mathbf{G}=$ grass.

of tree, shrub, herb and grass. $58.33 \%$ of the species assessed are herbs, $25 \%$ are trees, $8.33 \%$ are shrub and $4.17 \%$ are grasses (Figure 1). 


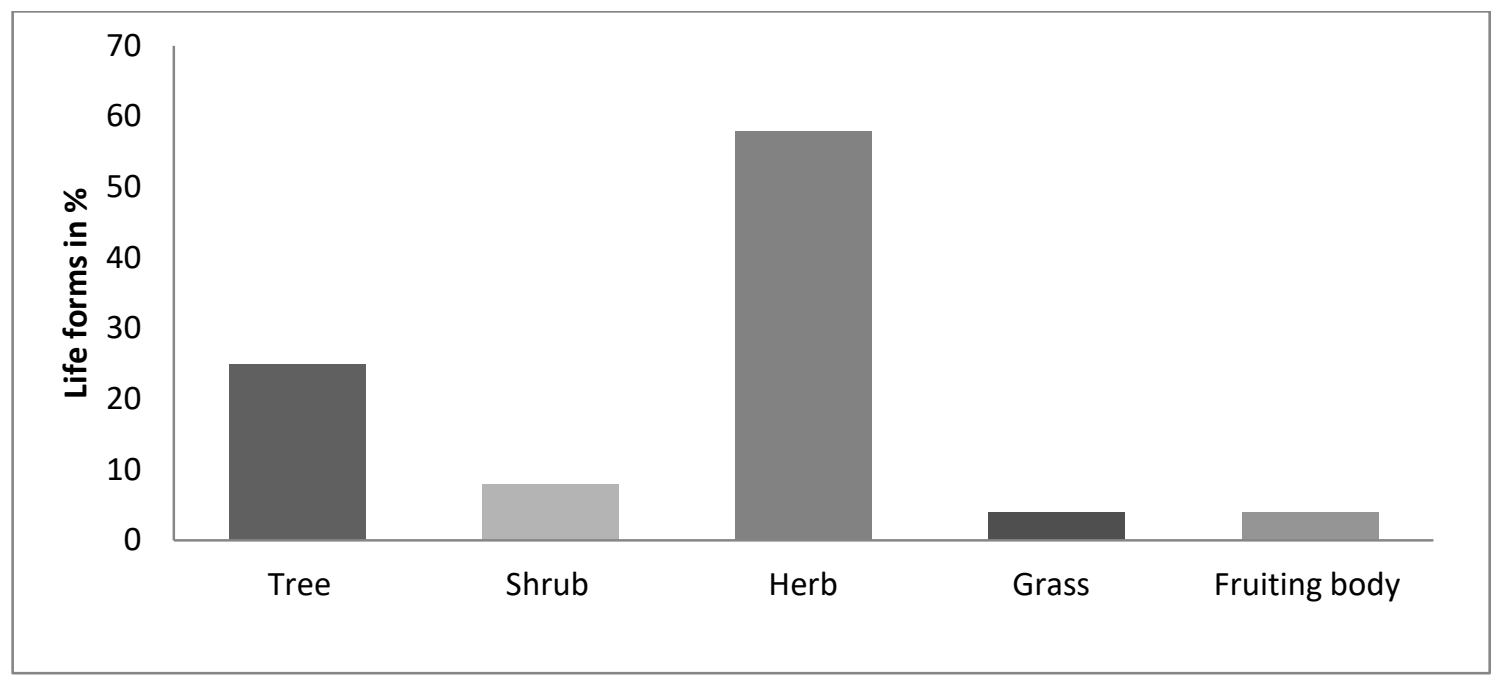

Figure 1. Life forms of spices in Bayelsa State, Nigeria.

The botanicals are either cultivated or sourced from the wild. $62.5 \%$ of the spice plants are sourced from the wild, while $37.5 \%$ are cultivated (Table 2). The parts of the botanicals utilized for spice include: fruit/seed, leaf/shoot, bulb, rhizome and an entirepart. A number of reasons explain respondents' choice of a particular spice plant, these include healthcare, cuisine, taboos among other things. However, dose formulation depends on cuisine and user's taste (Table 2). The table also shows that most of the techniques used for harvesting the botanicals are hazardous. $\mathrm{X}^{2}$ test revealed that there is no significant difference $(p>0.05)$ in the occurrence of spicy plants in the three zones, an indication that spicy plants are heterogeneously distributed in the zones.

Table 2. Features of spicy plants utilized among major ethnic group in Bayelsa State of Nigeria.

\begin{tabular}{|c|c|c|c|c|c|c|}
\hline & $\begin{array}{l}\text { Botanical } \\
\text { names }\end{array}$ & $\begin{array}{c}\text { Method of } \\
\text { harvest }\end{array}$ & $\begin{array}{c}\text { Abundance } \\
\text { status }\end{array}$ & $\begin{array}{c}\text { Dose } \\
\text { formulation }\end{array}$ & $\begin{array}{c}\text { Reasons for } \\
\text { choice }\end{array}$ & PS* \\
\hline 1 & $\begin{array}{l}\text { Aframomum } \\
\text { citratum }\end{array}$ & $\mathrm{P} / \mathrm{A}$ & Frequent & $\begin{array}{l}\text { Quantity } \\
\text { depends on } \\
\text { cuisine \& } \\
\text { user's taste }\end{array}$ & $\begin{array}{c}\text { Gives } \\
\text { characteristic } \\
\text { taste and } \\
\text { peppering } \\
\text { sensation. }\end{array}$ & Wild \\
\hline 2 & $\begin{array}{l}\text { Aframomum } \\
\text { danielli }\end{array}$ & $\mathrm{P} / \mathrm{A}$ & " & " & $" \prime$ & Wild \\
\hline 3 & $\begin{array}{l}\text { Aframomum } \\
\text { melegueta }\end{array}$ & $\mathrm{P} / \mathrm{A}$ & Occasional & " & $\begin{array}{l}\text { Gives } \\
\text { characteristic } \\
\text { piquant taste. }\end{array}$ & Wild \\
\hline 4 & $\begin{array}{ll}\text { Agaricus } & s p ., \\
\text { Lentinus } & \\
\text { tuberregium } & \\
\end{array}$ & $\mathrm{NP} / \mathrm{G}$ & Very abundant & “ & $\begin{array}{l}\text { Soup thickener } \\
\text { gives flavour }\end{array}$ & Wild \\
\hline 5 & $\begin{array}{l}\text { Alchornea } \\
\text { cordifolia }\end{array}$ & $\mathrm{NP} / \mathrm{G}$ & “ & " & $\begin{array}{l}\text { Gives additional } \\
\text { flavour to taste }\end{array}$ & Wild \\
\hline
\end{tabular}


Table 2. Continued.

\begin{tabular}{|c|c|c|c|c|c|c|}
\hline & $\begin{array}{l}\text { Botanical } \\
\text { names }\end{array}$ & $\begin{array}{c}\text { Method of } \\
\text { harvest }\end{array}$ & $\begin{array}{c}\text { Abundance } \\
\text { status }\end{array}$ & $\begin{array}{c}\text { Dose } \\
\text { formulation }\end{array}$ & $\begin{array}{l}\text { Reasons for } \\
\text { choice }\end{array}$ & PS* \\
\hline 6 & Allium сера & $\mathrm{P} / \mathrm{A}$ & Abundant & " & $\begin{array}{c}\text { Gives } \\
\text { characteristic } \\
\text { taste and } \\
\text { additional } \\
\text { flavour to food }\end{array}$ & Cultivated \\
\hline 7 & Allium sativum & $\mathrm{P} / \mathrm{A}$ & $"$ & $"$ & $"$ & Cultivated \\
\hline 8 & $\begin{array}{l}\text { Capsicum } \\
\text { annuum }\end{array}$ & $\mathrm{NP} / \mathrm{G}$ & Very abundant & " & $\begin{array}{c}\text { Gives } \\
\text { characteristic } \\
\text { peppery } \\
\text { sensation } \\
\end{array}$ & Cultivated \\
\hline 9 & $\begin{array}{l}\text { Chromolaena } \\
\text { odoratum }\end{array}$ & $\mathrm{NP} / \mathrm{G}$ & $"$ & $"$ & $\begin{array}{c}\text { Give food } \\
\text { identifiable taste. }\end{array}$ & Wild \\
\hline 10 & Citrus sinensis & $\mathrm{P} / \mathrm{A}$ & " & $"$ & $\begin{array}{c}\text { Give food } \\
\text { characteristic } \\
\text { tang taste and } \\
\text { flavour }\end{array}$ & Cultivated \\
\hline 11 & $\begin{array}{l}\text { Cymlopogon } \\
\text { citratus }\end{array}$ & $\mathrm{P} / \mathrm{A}$ & Abundant & $"$ & $\begin{array}{c}\text { Flavour, } \\
\text { characteristic } \\
\text { tang taste \& } \\
\text { aroma }\end{array}$ & Cultivated \\
\hline 12 & $\begin{array}{l}\text { Dennettia } \\
\text { tripetala }\end{array}$ & $\mathrm{NP} / \mathrm{G}$ & Rare & “ & $\begin{array}{c}\text { Gives } \\
\text { characteristic } \\
\text { peppery } \\
\text { sensation. }\end{array}$ & Wild \\
\hline 13 & Irvingia smittii & $\mathrm{NP} / \mathrm{G}$ & $"$ & $"$ & $\begin{array}{c}\text { Soup thickener, } \\
\text { enhance taste }\end{array}$ & Wild \\
\hline 14 & $\begin{array}{l}\text { Monodora } \\
\text { myristica }\end{array}$ & $\mathrm{NP} / \mathrm{G}$ & Frequent & $"$ & $\begin{array}{l}\text { Characteristic } \\
\text { taste } \\
\end{array}$ & Wild \\
\hline 15 & Murraya koenigii & $\mathrm{NP} / \mathrm{G}$ & Abundant & $"$ & $\begin{array}{c}\text { Gives } \\
\text { characteristic } \\
\text { taste, and smell. }\end{array}$ & Cultivated \\
\hline 16 & $\begin{array}{l}\text { Ocimum } \\
\text { basilicum }\end{array}$ & $\mathrm{NP} / \mathrm{G}$ & Very abundant & $"$ & $\begin{array}{l}\text { Gives identifiable } \\
\text { taste and flavour }\end{array}$ & Wild \\
\hline 17 & $\begin{array}{l}\text { Pennistum } \\
\text { purpureum }\end{array}$ & $\mathrm{NP} / \mathrm{G}$ & $"$ & " & Give taste & Wild \\
\hline 18 & Piper guineense & $\mathrm{NP} / \mathrm{G}$ & Frequent & “ & $\begin{array}{c}\text { Gives food } \\
\text { characteristic } \\
\text { taste and smell. }\end{array}$ & Wild \\
\hline 19 & $\begin{array}{l}\text { Telfairia } \\
\text { occidentalis }\end{array}$ & $\mathrm{NP} / \mathrm{G}$ & Very abundant & $"$ & $\begin{array}{l}\text { Soup thickener, } \\
\text { gives flavour. }\end{array}$ & Cultivated \\
\hline 20 & $\begin{array}{l}\text { Tetrapleura } \\
\text { tetraptera }\end{array}$ & $\mathrm{NP} / \mathrm{G}$ & Occasional & $"$ & $\begin{array}{c}\text { Gives } \\
\text { characteristic } \\
\text { taste and smell }\end{array}$ & Wild \\
\hline 21 & $\begin{array}{l}\text { Vernonia } \\
\text { amygdalina }\end{array}$ & $\mathrm{NP} / \mathrm{G}$ & Very abundant & " & $\begin{array}{c}\text { Gives identifiable } \\
\text { taste and } \\
\text { flavour to soup. }\end{array}$ & Cultivated \\
\hline 22 & $\begin{array}{l}\text { Xanthosoma } \\
\text { mafaffa }\end{array}$ & $\mathrm{NP} / \mathrm{G}$ & " & " & $\begin{array}{c}\text { Give additional } \\
\text { flavour }\end{array}$ & Cultivated \\
\hline
\end{tabular}


Table 2. Continued.

\begin{tabular}{|l|l|c|c|c|c|c|}
\hline & $\begin{array}{l}\text { Botanical } \\
\text { names }\end{array}$ & $\begin{array}{c}\text { Method of } \\
\text { harvest }\end{array}$ & $\begin{array}{c}\text { Abundance } \\
\text { status }\end{array}$ & $\begin{array}{c}\text { Dose } \\
\text { formulation }\end{array}$ & $\begin{array}{c}\text { Reasons for } \\
\text { choice }\end{array}$ & PS* \\
\hline 23 & $\begin{array}{l}\text { Xylopia } \\
\text { aethiopica }\end{array}$ & P/A & Rare & $\begin{array}{c}\text { Flavouring, give } \\
\text { characteristic } \\
\text { taste. }\end{array}$ & Wild \\
\hline 24 & $\begin{array}{l}\text { Zingiber } \\
\text { officinale }\end{array}$ & P/A & Frequent & " & $\begin{array}{c}\text { Gives identifiable } \\
\text { taste and flavour }\end{array}$ & Wild \\
\hline
\end{tabular}

Very abundant $=41.67 \%$; Abundant $=16.67 \%$; Frequent $=20.83 \%$; Occasional $=8.33 \%$; Rare $=$ 12.5\%. *Plant source, Wild $=62.5 \%$, Cultivated $=37.5 \%, \mathrm{P} / \mathrm{A}=$ Predatory $/$ Annihilation $37.5 \%$; $\mathrm{NP} / \mathrm{G}=$ Non Predatory/Gathering 62.5\%.

Fruit/seed are the most utilize parts of spice plants, these account for $45.83 \%$. While Rhizome and the entireparts are the least utilized parts, and they account for $4.17 \%$ each (Table 3 ). The methods used for harvesting spicy session of the plant species in approximately $38 \%$ of the spicy plants are done predatorily and annihilatively (Table 2). Predatory/annihilative (P/A) techniques are often employed for harvest in the study area; it involves felling and or uprooting of spicy plants. Kayode and Ogundele (2008) identified the techniques as the most destructive method of harvesting spicy plants. Xylopia aethiopica is the main victim of such practices; it is often fell before its fruits are harvested. Also members of the Zingiberaceae, Bulb and rhizome that are sourced from the wild suffer similar fate; and their regeneration rates lag behind the rate at which they are harvested. P/A techniques lead to rarity of the spicy plants. On the other hand, $62.5 \%$ of the methods of harvesting spicy plants in the study area are Non Predatory/Gathering (NP/G) (Table 2). Despite the fact that NP/G methods are used to harvest large proportion of the spicy parts such methods are lethal, because they are done not without damages to the branches and other vital organs of the plants. Main while, a total of $12.5 \%$ of the spicy plants are found to be rare, $8.33 \%$ as occasional and $20.83 \%$ as frequent (Table 2), these might not be unconnected to over exploitation and environmental pollution. The level of familiarities with spice plants among respondents is enormous, knowledge of spicy plants transverses sex, age, literacy status, occupation, location and religion affiliates of the respondents (Table 4). Women tend to purpose much knowledge of spicy plants than their male counterpart.

Table 3. Part utilized in the identified spice plants in Bayelsa State, Nigeria.

\begin{tabular}{|l|l|c|}
\hline Parts utilized & Botanical species & $\begin{array}{c}\text { Proportion (\%) } \\
\text { of the botanicals }\end{array}$ \\
\hline Fruits/ seeds & $\begin{array}{l}\text { A. citratum, A. danielli, A melegueta, C. annuum, D. tripetala, } \\
\text { l. Smittii, M. myristica, P. guineense, T. tetraptera, X } \\
\text { aethiopica, T. occidentalis }\end{array}$ & 45.83 \\
\hline Leaves/shoot & $\begin{array}{l}\text { A. cordifolia, C. odoratum, O. gratissimum, C. sinensis, C. } \\
\text { citrates, P. purpureum, V. amygdalina, X. mafaffa, M. koenigii }\end{array}$ & 37.5 \\
\hline Bulb & A. cepa, A. sativum & 8.33 \\
\hline Rhizome & Z. officinale & 4.17 \\
\hline Entire part & Agaricus sp. (edible mushrooms) & 4.17 \\
\hline
\end{tabular}


Table4. Socio-economic status of respondents in the study area.

\begin{tabular}{|c|c|c|c|c|}
\hline & & BW\% & BC\% & BE\% \\
\hline Sex & $\begin{array}{l}\text { male } \\
\text { female }\end{array}$ & $\begin{array}{l}25 \\
75\end{array}$ & $\begin{array}{c}38 \\
112 \\
\end{array}$ & $\begin{array}{c}35 \\
115 \\
\end{array}$ \\
\hline Age & $\begin{array}{l}<20 \\
20-65 \\
>65\end{array}$ & $\begin{array}{l}29 \\
16 \\
16 \\
\end{array}$ & $\begin{array}{l}42 \\
39 \\
39 \\
\end{array}$ & $\begin{array}{l}34 \\
40 \\
40 \\
\end{array}$ \\
\hline Religion & $\begin{array}{l}\text { Christian } \\
\text { Moslem } \\
\text { Others }\end{array}$ & $\begin{array}{c}87 \\
- \\
13 \\
\end{array}$ & $\begin{array}{c}131 \\
- \\
19 \\
\end{array}$ & $\begin{array}{c}118 \\
- \\
32 \\
\end{array}$ \\
\hline Literacy status: & $\begin{array}{l}\text { Literate } \\
\text { illiterate }\end{array}$ & $\begin{array}{l}56 \\
44 \\
\end{array}$ & $\begin{array}{c}110 \\
40 \\
\end{array}$ & $\begin{array}{l}93 \\
57\end{array}$ \\
\hline Econ. status: & $\begin{array}{l}\text { small } \\
\text { Medium } \\
\text { Large }\end{array}$ & $\begin{array}{c}48 \\
44 \\
8 \\
\end{array}$ & $\begin{array}{l}69 \\
70 \\
11 \\
\end{array}$ & $\begin{array}{l}61 \\
24 \\
65 \\
\end{array}$ \\
\hline Occupation: & $\begin{array}{l}\text { Agriculture } \\
\text { Non agriculture }\end{array}$ & $\begin{array}{l}87 \\
13\end{array}$ & $\begin{array}{c}129 \\
21\end{array}$ & $\begin{array}{c}126 \\
24\end{array}$ \\
\hline Location: & $\begin{array}{l}\text { Onshore } \\
\text { Offshore }\end{array}$ & $\begin{array}{l}70 \\
30\end{array}$ & $\begin{array}{c}110 \\
40\end{array}$ & $\begin{array}{l}60 \\
90\end{array}$ \\
\hline
\end{tabular}

In spite of the importance of NTFPs in term of their economic value: factors such as exploitation, crude oil pollution and forest timber exploitation are responsible for their constant depletion in the study area. It is important to seek for ways that will ensure their conservation. Hence, the need to harvest (spicy trees) by pruning rather than by the use of total annihilation methods being practiced in the area; moreover bunkery activities should be discourage to forestall land pollutions, a key factor responsible for deforestation in the study area. The gazetted reserves in the State should be properly managed and Forest laws should be enforced in the study area.

\section{Conflict of interest statement}

The authors declare that they have no competing interests.

\section{References}

Achinewu, S. C.; Aniena, M. I.; Obomanu, F. G. Studies on spices of food value in the South Eastern States of Nigeria 1: Antioxidants Properties. J. Afri. Med. Plants, v. 18, p. 135139, 1995.
Akpokodje, E. G. Preliminary studies on the geotechnical characteristics of the Niger Delta subsoil. Engineering Geology, v. 26, p. 247-257, 1989.

FAO - Food and Agricultural Organization. Food and Agricultural Organization Statistics. Rome: FAO, 2005.

Gill, L. S. Ethnomedicinal uses of plans in Nigeria. Benin-City, Nigeria: Uniben Press, 1992.

Hutchinson, J.; Dalziel, J. M. Flora of West Tropical Africa. Whitefriars Press, 1954. v. 1.

Kamala, K. Traditional Indian spices and their health significance. Asia Pac. J. Clin. Nutr., v. 17, no. 1, p. 265-268, 2008.

Kayode, J. Ethnobotanical survey and conservation of plant species used for curing malaria in Edo and Ekiti States of Nigeria. NISEB Journal, v. 2, no. 4, p. 247-252, 2002.

Kayode, J. Ethnobotanical survey and conservation of medicinal compositae species in Benin Kingdom, Nigeria. 2005.

Kayode, J.; Ogunleye, T. Checklist and status of plant species used as spices in Kaduna State of Nigeria. Research Journal of Botany, v. 3, no. 1, p. 35-40, 2008.

Keay, R. W. J.; Onochie, C. F. A.; Stanfield, D. P. Nigerian trees. Ibadan: Department of Forest Research, 1964. v. 1 and 2. 
MacMillian, H. F. A Handbook for tropical planting and gardening. London: MacMillan Scientific Publ., 1984.

Mathewo, A. Ethnobotany of spice and condiment plants and the associated indigenous knowledge on management, utilization and conservation of them in and around home gardens in Loma and Gena Bosa Districts (Weredas) of Dawuro Zone, Southern Ethiopia. International Journal of Agriculture Innovations and Research, v. 4, p. 2319-1473, 2015.
Nyananyo, B. L. Plants from the Niger Delta. Niger: Onyoma Research Publications, 2006.

Olife, I. C.; Onwualu, A. P.; Uchegbu, K. I.; Jolaoso, M. A. Status assessment of spice resources in Nigeria. Journal of Biology, Agriculture and Healthcare, v. 3, no. 9, p. 2224-3208, 2013.

Soladoye, M. O.; Sonibare, M. A. Non-timber forest products of Old Oyo National Park and their sustainability. Nigerian J. of Bot., v. 16, 16-32, 2003. 